\title{
Effect of NPK and Poultry Manure on Growth, Yield, and Proximate Composition of Three Amaranths
}

\author{
Stephen Oyedeji, ${ }^{1}$ David Adedayo Animasaun, \\ Abdullahi Ajibola Bello, ${ }^{1}$ and Oludare Oladipo Agboola ${ }^{2}$ \\ ${ }^{1}$ Department of Plant Biology, University of Ilorin, PMB 1515, Ilorin 240003, Nigeria \\ ${ }^{2}$ Biology Department, The Polytechnic Ibadan, PMB 22, Ibadan 200284, Nigeria \\ Correspondence should be addressed to Stephen Oyedeji; oyedeji.s@unilorin.edu.ng
}

Received 1 October 2013; Accepted 3 December 2013; Published 12 January 2014

Academic Editor: Muhammad Y. Ashraf

Copyright (C) 2014 Stephen Oyedeji et al. This is an open access article distributed under the Creative Commons Attribution License, which permits unrestricted use, distribution, and reproduction in any medium, provided the original work is properly cited.

The study compares the growth, yield, and proximate composition of Amaranthus hybridus, Amaranthus cruentus, and Amaranthus deflexus, grown with poultry manure and NPK in relation to the unfertilized soil of Ilorin, Nigeria. Viable seeds of the Amaranths raised in nursery for two weeks were transplanted (one plant per pot) into unfertilized soil (control) and soils fertilized with either NPK or poultry manure (PM) at $30 \mathrm{Kg} \mathrm{ha}^{-1}$ rate arranged in randomized complete block design with four replicates. Data were collected on plant height, stem girth, number of leaves, leaf area, and number of branches from 1 week after transplanting (1 WAT). Fresh weight, dry weight, and proximate composition were determined at 6 WAT. Except for the length, breadth, and number of leaves, the order of growth parameters and yield in the three Amaranthus species was NPK > PM $>$ control. NPK grown Amaranthus species had the highest protein while PM-grown vegetables had the highest ash content. Crude fibre in A. cruentus grown with PM was significantly higher than NPK and the control. The NPK treatment of A. hybridus and A. deflexus had the highest crude fibre content. NPK and PM favoured growth and yield of the Amaranthus species but influenced proximate composition differently.

\section{Introduction}

In Nigeria, as in most other tropical countries of Africa where the daily diet is dominated by starchy staple foods, vegetables are the cheapest and most readily available sources of important proteins, vitamins minerals, and essential amino acids [1]. Of all vegetables, Talinum triangulare, Telfaria occidentalis, Corchorus olitorius, Vernonia amygdalina, and Amaranthus species such as A. hybridus, A. cruentus, A. caudatus, and $A$. deflexus are mostly consumed. The production and nutritional values of these vegetables are limited due to the low fertility of native soils in most parts of Nigeria [2]. The use of inorganic fertilizer to increase yield has been found to be effective only within few years, demanding consistent use on long-term basis [3]. The hazardous environmental consequences and high cost of inorganic fertilizers make them not only undesirable but also uneconomical and out of reach of the poor farmers who still dominate the Nigerian agricultural sector [4]. This has led to increased use of organic manure, a readily available alternative, which proves more environmentally friendly.

In recent times, attention has been directed towards organic manure because of the rising cost of inorganic fertilizers coupled with their inability to give the soil the desired sound health. Poultry manure, sometimes called chicken manure, is an excellent soil amendment that provides nutrients for growing crops and also improves soil quality when applied wisely, because it has high organic matter content combined with available nutrients for plant growth [5]. The chemical composition of poultry manure varies with factors such as source of manure, feed of the birds, age and condition of the birds, storage, handling of manure, and litter used [6]. Poultry waste consists of droppings, wasted feed, broken eggs, feathers, and sometimes sawdust from poultry floor. It also includes the dead birds and hatchery waste, all of which are high in protein and contain substantial amount 
TABLE 1: Number of leaves in three Amaranthus species grown in fertilized and unfertilized soil from 1 to 6 weeks after transplanting.

\begin{tabular}{|c|c|c|c|c|c|c|c|}
\hline \multirow{2}{*}{ Amaranth } & \multirow{2}{*}{ Treatments } & \multicolumn{6}{|c|}{ Number of leaves } \\
\hline & & $1 \mathrm{WAT}$ & $2 \mathrm{WAT}$ & 3 WAT & $4 \mathrm{WAT}$ & 5 WAT & $6 \mathrm{WAT}$ \\
\hline \multirow{3}{*}{ A. hybridus } & Control & $6^{\mathrm{ab}}$ & $15^{\mathrm{a}}$ & $19^{\mathrm{a}}$ & $27^{\mathrm{a}}$ & $23^{\mathrm{a}}$ & $25^{\mathrm{a}}$ \\
\hline & $\mathrm{PM}$ & $7^{\mathrm{a}}$ & $18^{\mathrm{a}}$ & $22^{\mathrm{a}}$ & $30^{\mathrm{a}}$ & $28^{\mathrm{a}}$ & $25^{\mathrm{a}}$ \\
\hline & NPK & $4^{\mathrm{b}}$ & $7^{\mathrm{b}}$ & $16^{\mathrm{a}}$ & $27^{\mathrm{a}}$ & $24^{\mathrm{a}}$ & $21^{\mathrm{a}}$ \\
\hline \multirow{3}{*}{ A. cruentus } & Control & $8^{\mathrm{a}}$ & $16^{\mathrm{ab}}$ & $28^{\mathrm{a}}$ & $34^{\mathrm{a}}$ & $31^{\mathrm{a}}$ & $28^{\mathrm{a}}$ \\
\hline & $\mathrm{PM}$ & $8^{\mathrm{a}}$ & $22^{\mathrm{a}}$ & $28^{\mathrm{a}}$ & $35^{\mathrm{a}}$ & $34^{\mathrm{a}}$ & $31^{\mathrm{a}}$ \\
\hline & NPK & $6^{\mathrm{a}}$ & $12^{\mathrm{b}}$ & $28^{\mathrm{a}}$ & $36^{\mathrm{a}}$ & $32^{\mathrm{a}}$ & $32^{\mathrm{a}}$ \\
\hline \multirow{3}{*}{ A. deflexus } & Control & $9^{a}$ & $36^{\mathrm{a}}$ & $44^{\mathrm{a}}$ & $49^{\mathrm{a}}$ & $54^{\mathrm{a}}$ & $57^{\mathrm{a}}$ \\
\hline & $\mathrm{PM}$ & $7^{\mathrm{a}}$ & $18^{\mathrm{a}}$ & $29^{\mathrm{b}}$ & $37^{\mathrm{a}}$ & $41^{\mathrm{a}}$ & $39^{\mathrm{b}}$ \\
\hline & NPK & $10^{\mathrm{a}}$ & $24^{\mathrm{b}}$ & $36^{\mathrm{b}}$ & $44^{\mathrm{a}}$ & $53^{\mathrm{a}}$ & $59^{\mathrm{a}}$ \\
\hline
\end{tabular}

${ }^{*}$ Comparison is treatment-wise. Means with the same letter(s) within each species are not significant at $P<0.05$.

TABLE 2: Leaf length in three Amaranthus species grown in fertilized and unfertilized soil from 1 to 6 weeks after transplanting.

\begin{tabular}{|c|c|c|c|c|c|c|c|}
\hline \multirow{2}{*}{ Amaranth } & \multirow{2}{*}{ Treatments } & \multicolumn{6}{|c|}{ Leaf length (mm) } \\
\hline & & $1 \mathrm{WAT}$ & $2 \mathrm{WAT}$ & $3 \mathrm{WAT}$ & 4 WAT & $5 \mathrm{WAT}$ & 6 WAT \\
\hline \multirow{3}{*}{ A. hybridus } & Control & $3.73^{\mathrm{a}}$ & $9.30^{\mathrm{ab}}$ & $12.60^{\mathrm{a}}$ & $15.80^{\mathrm{b}}$ & $16.23^{\mathrm{b}}$ & $16.66^{\mathrm{b}}$ \\
\hline & $\mathrm{PM}$ & $4.60^{\mathrm{a}}$ & $11.40^{\mathrm{a}}$ & $14.56^{\mathrm{a}}$ & $15.50^{\mathrm{b}}$ & $16.16^{\mathrm{b}}$ & $16.40^{\mathrm{b}}$ \\
\hline & NPK & $3.13^{\mathrm{a}}$ & $5.46^{\mathrm{b}}$ & $12.46^{\mathrm{a}}$ & $24.00^{\mathrm{a}}$ & $27.20^{\mathrm{a}}$ & $28.36^{\mathrm{a}}$ \\
\hline \multirow{3}{*}{ A. cruentus } & Control & $3.66^{\mathrm{a}}$ & $8.83^{\mathrm{ab}}$ & $12.26^{\mathrm{a}}$ & $12.93^{\mathrm{b}}$ & $13.53^{\mathrm{b}}$ & $13.93^{\mathrm{b}}$ \\
\hline & $\mathrm{PM}$ & $4.30^{\mathrm{a}}$ & $10.66^{\mathrm{a}}$ & $12.70^{\mathrm{a}}$ & $14.00^{\mathrm{b}}$ & $14.73^{\mathrm{b}}$ & $15.06^{\mathrm{b}}$ \\
\hline & NPK & $2.90^{\mathrm{a}}$ & $6.73^{\mathrm{b}}$ & $14.73^{\mathrm{a}}$ & $18.36^{\mathrm{a}}$ & $19.00^{\mathrm{a}}$ & $20.10^{\mathrm{a}}$ \\
\hline \multirow{3}{*}{ A. deflexus } & Control & $4.00^{\mathrm{a}}$ & $10.63^{\mathrm{a}}$ & $12.53^{\mathrm{a}}$ & $13.83^{\mathrm{a}}$ & $14.20^{\mathrm{a}}$ & $14.16^{\mathrm{b}}$ \\
\hline & $\mathrm{PM}$ & $2.80^{\mathrm{b}}$ & $8.03^{\mathrm{b}}$ & $11.46^{\mathrm{a}}$ & $12.56^{\mathrm{a}}$ & $13.26^{\mathrm{a}}$ & $13.43^{\mathrm{b}}$ \\
\hline & NPK & $4.16^{\mathrm{a}}$ & $10.30^{\mathrm{a}}$ & $11.50^{\mathrm{a}}$ & $14.26^{\mathrm{a}}$ & $15.53^{\mathrm{a}}$ & $16.83^{\mathrm{a}}$ \\
\hline
\end{tabular}

${ }^{*}$ Comparison is treatment-wise. Means with the same letter(s) within each species are not significant at $P<0.05$.

of calcium and phosphorus due to high level of mineral supplement in their diet. Poultry manure has been reported to contain more plant nutrients than all other organic manures [7].

At present, vegetable farmers mostly apply poultry manure in combination with inorganic nitrogen-based fertilizers such as Urea and NPK [8], often because poultry manure alone is believed to dissolve slowly and may not meet up the yield of vegetables. There is a need to determine the independent influence of poultry manure and inorganic nitrogen fertilizer such as NPK on the growth, yield, and nutritional quality of fast-growing vegetables like Amaranthus species as to justify the continuous mixture of both or otherwise. The present study compares the growth, yield, and proximate composition of three Amaranthus species-A. hybridus, A. cruentus, and $A$. deflexus, grown with poultry manure, NPK in relation to the unfertilized (control) soil.

\section{Materials and Methods}

The potted experiment was set up in a screen house in 2013 at the University of Ilorin ( $\mathrm{N} 08^{\circ} 28^{\prime} 53.3^{\prime \prime}$, E $04^{\circ} 40^{\prime} 28.9^{\prime \prime}$ ), Ilorin, Nigeria which lies in the southern guinea savanna belt of Nigeria. The annual rainfall in the area is about $1200 \mathrm{~mm}$ and temperature varies between $33^{\circ} \mathrm{C}$ and $34^{\circ} \mathrm{C}$ during the year, with a distinct dry season from December to March.
The effects of inorganic fertilizer (NPK-15:15:15) and organic fertilizer (poultry manure) were tested on growth, yield, and proximate composition of three species of Amaranthus-A. cruentus, A. hybridus, and A. deflexus. Viable seeds of the three species were obtained from the National Centre Genetic Research and Biotechnology, Moor Plantation, Ibadan, Nigeria. Seed viability testing was determined using floatation method [9]. The seeds were raised in nursery for two weeks and one plant per pot $(0.30 \mathrm{~m}$ by $0.38 \mathrm{~m}$ diameter by depth) was transplanted into the unfertilized soil (control) and soils fertilized with either NPK or poultry manure $(\mathrm{PM})$ at $30 \mathrm{~kg} \cdot \mathrm{ha}^{-1}$ rate incorporated into $12 \mathrm{~kg}$ top soil. The treatments were arranged in a randomized complete block design with four replicates. Weeds were handpicked and irrigation was done regularly at the same rate. Data collection on plant height, stem girth, number of leaves, leaf area, and number of branches was started 1 week after transplanting. The plants were harvested 6 weeks after transplanting and weighed fresh and dried. The proximate composition of moisture, protein, ash, fibre, and carbohydrate content was determined. The moisture content determination was done according to the method described by [10]. The crude protein, calculated from $6.25 \times \%$ nitrogen, was determined by microKjeldahl procedure of digestion, distillation, and titration according to AOAC procedure [11]. The ash content was expressed as the percentage weight of ash produced to 
TABLE 3: Leaf breadth in three Amaranthus species grown in fertilized and unfertilized soil from 1 to 6 weeks after transplanting.

\begin{tabular}{|c|c|c|c|c|c|c|c|}
\hline \multirow{2}{*}{ Amaranth } & \multirow{2}{*}{ Treatments } & \multicolumn{6}{|c|}{ Leaf breadth $(\mathrm{mm})$} \\
\hline & & $1 \mathrm{WAT}$ & 2 WAT & 3 WAT & 4 WAT & 5 WAT & $6 \mathrm{WAT}$ \\
\hline \multirow{3}{*}{ A. hybridus } & Control & $1.50^{\mathrm{a}}$ & $4.90^{\mathrm{ab}}$ & $6.63^{\mathrm{a}}$ & $7.53^{\mathrm{b}}$ & $7.96^{\mathrm{b}}$ & $8.13^{\mathrm{b}}$ \\
\hline & $\mathrm{PM}$ & $2.10^{\mathrm{a}}$ & $6.00^{\mathrm{a}}$ & $7.16^{\mathrm{a}}$ & $7.90^{\mathrm{b}}$ & $8.20^{\mathrm{b}}$ & $8.43^{\mathrm{b}}$ \\
\hline & NPK & $1.50^{\mathrm{a}}$ & $2.56^{\mathrm{b}}$ & $7.63^{\mathrm{a}}$ & $11.33^{\mathrm{a}}$ & $13.13^{\mathrm{a}}$ & $14.03^{\mathrm{a}}$ \\
\hline \multirow{3}{*}{ A. cruentus } & Control & $1.46^{\mathrm{a}}$ & $4.33^{\mathrm{ab}}$ & $6.16^{\mathrm{a}}$ & $6.36^{\mathrm{b}}$ & $6.66^{\mathrm{b}}$ & $6.53^{\mathrm{b}}$ \\
\hline & $\mathrm{PM}$ & $1.90^{\mathrm{a}}$ & $5.33^{\mathrm{a}}$ & $6.20^{\mathrm{a}}$ & $6.93^{\mathrm{b}}$ & $7.23^{\mathrm{b}}$ & $6.90^{\mathrm{b}}$ \\
\hline & NPK & $1.30^{\mathrm{a}}$ & $3.33^{\mathrm{b}}$ & $7.60^{\mathrm{a}}$ & $8.76^{\mathrm{a}}$ & $9.16^{\mathrm{a}}$ & $9.60^{\mathrm{a}}$ \\
\hline \multirow{3}{*}{ A. deflexus } & Control & $1.76^{\mathrm{a}}$ & $2.93^{\mathrm{b}}$ & $3.43^{\mathrm{a}}$ & $3.83^{\mathrm{b}}$ & $4.30^{\mathrm{a}}$ & $3.73^{\mathrm{b}}$ \\
\hline & $\mathrm{PM}$ & $1.23^{\mathrm{b}}$ & $2.63^{\mathrm{b}}$ & $3.60^{\mathrm{a}}$ & $3.83^{\mathrm{b}}$ & $4.06^{\mathrm{a}}$ & $3.50^{\mathrm{b}}$ \\
\hline & NPK & $1.83^{\mathrm{a}}$ & $3.86^{\mathrm{a}}$ & $4.16^{\mathrm{a}}$ & $4.93^{\mathrm{a}}$ & $5.23^{\mathrm{a}}$ & $4.80^{\mathrm{a}}$ \\
\hline
\end{tabular}

${ }^{*}$ Comparison is treatment-wise. Means with the same letter(s) within each species are not significant at $P<0.05$.

TABLE 4: The plant height of three Amaranthus species grown in fertilized and unfertilized soil from 1 to 6 weeks after transplanting.

\begin{tabular}{|c|c|c|c|c|c|c|c|}
\hline \multirow{2}{*}{ Amaranth } & \multirow{2}{*}{ Treatments } & \multicolumn{6}{|c|}{ Plant height $(\mathrm{cm})$} \\
\hline & & 1WAT & 2 WAT & 3 WAT & 4 WAT & 5 WAT & 6 WAT \\
\hline \multirow{3}{*}{ A. hybridus } & Control & $9.70^{\mathrm{a}}$ & $16.53^{\mathrm{a}}$ & $29.36^{\mathrm{ab}}$ & $42.96^{\mathrm{a}}$ & $53.00^{\mathrm{b}}$ & $64.96^{\mathrm{b}}$ \\
\hline & PM & $11.00^{\mathrm{a}}$ & $24.66^{\mathrm{a}}$ & $38.30^{\mathrm{a}}$ & $53.73^{\mathrm{a}}$ & $65.73^{\mathrm{ab}}$ & $79.13^{\mathrm{b}}$ \\
\hline & NPK & $7.60^{\mathrm{a}}$ & $9.80^{\mathrm{a}}$ & $24.03^{\mathrm{b}}$ & $58.90^{\mathrm{a}}$ & $79.93^{\mathrm{b}}$ & $108.50^{\mathrm{a}}$ \\
\hline \multirow{3}{*}{ A. cruentus } & Control & $7.30^{\mathrm{a}}$ & $16.66^{\mathrm{a}}$ & $34.30^{\mathrm{a}}$ & $46.03^{\mathrm{b}}$ & $59.36^{\mathrm{a}}$ & $74.43^{\mathrm{b}}$ \\
\hline & $\mathrm{PM}$ & $9.20^{\mathrm{a}}$ & $5.83^{\mathrm{b}}$ & $37.70^{\mathrm{a}}$ & $55.00^{\mathrm{ab}}$ & $70.33^{\mathrm{a}}$ & $86.83^{\mathrm{ab}}$ \\
\hline & NPK & $7.90^{\mathrm{a}}$ & $10.30^{\mathrm{b}}$ & $39.33^{\mathrm{a}}$ & $65.23^{\mathrm{a}}$ & $77.60^{\mathrm{a}}$ & $100.66^{\mathrm{a}}$ \\
\hline \multirow{3}{*}{ A. deflexus } & Control & $5.93^{\mathrm{a}}$ & $10.13^{\mathrm{a}}$ & $29.43^{\mathrm{a}}$ & $61.20^{\mathrm{a}}$ & $89.20^{\mathrm{a}}$ & $106.00^{\mathrm{a}}$ \\
\hline & PM & $4.93^{\mathrm{b}}$ & $5.96^{\mathrm{b}}$ & $21.16^{\mathrm{b}}$ & $49.93^{\mathrm{a}}$ & $73.26^{\mathrm{a}}$ & $110.03^{\mathrm{a}}$ \\
\hline & NPK & $6.00^{\mathrm{a}}$ & $10.36^{\mathrm{a}}$ & $23.70^{\mathrm{ab}}$ & $51.16^{\mathrm{a}}$ & $67.26^{\mathrm{a}}$ & $84.66^{\mathrm{b}}$ \\
\hline
\end{tabular}

${ }^{*}$ Comparison is treatment-wise. Means with the same letter(s) within each species are not significant at $P<0.05$.

original weight of dried sample dry ash in muffle furnace at $600^{\circ} \mathrm{C}[10]$. Crude fibre determination was carried out on $2 \mathrm{~g}$ fat-free samples obtained after crude fat determination using Soxhlet procedure [12]. Total carbohydrate was calculated as the difference between 100 and the sum of the moisture, protein, fat, fibre, and ash contents [13]. Analysis of variance was performed on the data and means were separated using Duncan's multiple range test.

\section{Results}

The inorganic (NPK) and organic fertilizer (PM) generally increased the growth of all the species of Amaranthus in this study. This was revealed by the growth and luxuriance of the three Amaranthus species planted with fertilizers in the weeks after transplanting (WAT). However, NPK-grown A. hybridus and A. cruentus had fewer leaves than PM and the control. The NPK treatment of $A$. deflexus was significantly lower than the control only at 2 and 3 WAP (Table 1). Leaf length in the NPK-grown A. hybridus and $A$. cruentus was initially shorter than that in PM and control (1 WAT and 2 WAT) but it had the longest leaves at 6 WAT. A. deflexus grown with NPK had the longest leaves except at 2 and 3 WAP (Table 2). Results of leaf breadth in the three species were similar to those of leaf length as A. cruentus in the NPK-fertilized soil was initially lower than that in PM and control (at 2 WAT) but higher at later weeks (Table 3). Of the three treatments, plant height of A. hybridus in NPKtreated soil was shortest from 1WAT to 3 WAT, but this difference was only significant at 3 WAT. A. cruentus in NPKand PM-fertilized soils was significantly shorter than that of the control at 2 WAT but taller at 6 WAT. A. deflexus in the soil amended with NPK was shortest at 6 WAT (Table 4). The slow response of plants in the NPK-treated soil during the initial stage of the experiment may have influenced the stem girth of $A$. hybridus and $A$. cruentus at 1-2 WAT and 1 WAT, respectively, which had slimmer girths. A. deflexus in PM-treated soil had slimmer girths when compared with the control plants from 1 WAT to 3 WAT (Table 5). Only $A$. hybridus in NPK-treated soil had branches at 3 WAT, and the number was significantly different from PM and the control at 6 WAT. Only A. deflexus had branches at 2 WAT, with the NPK treatment having the significantly highest number of branches at 2 WAT and 3 WAT (Table 6). The weights (fresh and dry) of plants in the NPK-treated soil were significantly higher than PM and the control in all three species. The order of fresh weight and dry weight was similar in all the three Amaranthus species. A. hybridus had the highest fresh and dry weights of $66.52 \pm 7.84 \mathrm{~g}$ and $36.23 \pm 4.24 \mathrm{~g}$, respectively (Figure 1).

The proximate composition in all three species of Amaranthus due to the soil amendments varied for all parameter 
TABLE 5: Stem girths of three Amaranthus species grown in fertilized and unfertilized from 1 to 6 weeks after transplanting.

\begin{tabular}{|c|c|c|c|c|c|c|c|}
\hline \multirow{2}{*}{ Amaranth } & \multirow{2}{*}{ Treatments } & \multicolumn{6}{|c|}{ Stem girth $(\mathrm{mm})$} \\
\hline & & 1WAT & 2 WAT & 3 WAT & $4 \mathrm{WAT}$ & $5 \mathrm{WAT}$ & 6 WAT \\
\hline \multirow{3}{*}{ A. hybridus } & Control & $2.06^{\mathrm{a}}$ & $5.15^{\mathrm{ab}}$ & $7.50^{\mathrm{a}}$ & $10.63^{\mathrm{b}}$ & $12.74^{\mathrm{b}}$ & $13.67^{\mathrm{b}}$ \\
\hline & PM & $2.27^{\mathrm{a}}$ & $7.49^{\mathrm{a}}$ & $9.84^{\mathrm{a}}$ & $11.70^{\mathrm{b}}$ & $12.46^{\mathrm{b}}$ & $13.21^{\mathrm{b}}$ \\
\hline & NPK & $1.66^{\mathrm{a}}$ & $2.35^{\mathrm{b}}$ & $8.77^{\mathrm{a}}$ & $17.40^{\mathrm{a}}$ & $22.27^{\mathrm{a}}$ & $25.36^{\mathrm{a}}$ \\
\hline \multirow{3}{*}{ A. cruentus } & Control & $1.91^{\mathrm{a}}$ & $5.66^{\mathrm{a}}$ & $7.06^{\mathrm{a}}$ & $8.71^{\mathrm{b}}$ & $10.19^{\mathrm{b}}$ & $11.01^{\mathrm{b}}$ \\
\hline & $\mathrm{PM}$ & $2.65^{\mathrm{a}}$ & $3.63^{\mathrm{b}}$ & $8.50^{\mathrm{a}}$ & $9.67^{\mathrm{b}}$ & $11.75^{\mathrm{b}}$ & $13.38^{\mathrm{b}}$ \\
\hline & NPK & $1.76^{\mathrm{a}}$ & $4.98^{\mathrm{a}}$ & $10.78^{\mathrm{a}}$ & $17.33^{\mathrm{a}}$ & $23.36^{\mathrm{a}}$ & $27.38^{\mathrm{a}}$ \\
\hline \multirow{3}{*}{ A. deflexus } & Control & $2.21^{\mathrm{a}}$ & $5.66^{\mathrm{a}}$ & $7.39^{\mathrm{a}}$ & $9.14^{\mathrm{b}}$ & $9.71^{\mathrm{b}}$ & $10.54^{\mathrm{b}}$ \\
\hline & $\mathrm{PM}$ & $1.56^{\mathrm{b}}$ & $3.63^{\mathrm{b}}$ & $7.09^{\mathrm{a}}$ & $10.07^{\mathrm{ab}}$ & $10.77^{\mathrm{ab}}$ & $11.35^{\mathrm{ab}}$ \\
\hline & NPK & $2.23^{\mathrm{a}}$ & $4.98^{\mathrm{a}}$ & $8.09^{\mathrm{a}}$ & $10.75^{\mathrm{a}}$ & $11.56^{\mathrm{a}}$ & $12.00^{\mathrm{a}}$ \\
\hline
\end{tabular}

${ }^{*}$ Comparison is treatment-wise. Means with the same letter(s) within each species are not significant at $P<0.05$.

TABLE 6: Number of branches in three Amaranthus species grown in fertilized and unfertilized soil from 1 to 6 weeks after transplanting.

\begin{tabular}{|c|c|c|c|c|c|c|c|}
\hline \multirow{2}{*}{ Amaranth } & \multirow{2}{*}{ Treatments } & \multicolumn{6}{|c|}{ Number of branches } \\
\hline & & 1WAT & 2 WAT & 3 WAT & $4 \mathrm{WAT}$ & $5 \mathrm{WAT}$ & $6 \mathrm{WAT}$ \\
\hline \multirow{3}{*}{ A. hybridus } & Control & 0 & 0 & $0^{\mathrm{b}}$ & $5^{\mathrm{b}}$ & $8^{\mathrm{b}}$ & $11^{\mathrm{b}}$ \\
\hline & PM & 0 & 0 & $0^{\mathrm{b}}$ & $8^{\mathrm{b}}$ & $12^{\mathrm{b}}$ & $16^{\mathrm{b}}$ \\
\hline & NPK & 0 & 0 & $11^{\mathrm{a}}$ & $20^{\mathrm{a}}$ & $23^{\mathrm{a}}$ & $26^{\mathrm{a}}$ \\
\hline \multirow{3}{*}{ A. cruentus } & Control & 0 & 0 & $4^{\mathrm{b}}$ & $9^{c}$ & $13^{\mathrm{b}}$ & $16^{\mathrm{b}}$ \\
\hline & PM & 0 & 0 & $10^{\mathrm{a}}$ & $16^{\mathrm{b}}$ & $19^{\mathrm{b}}$ & $19^{\mathrm{b}}$ \\
\hline & NPK & 0 & 0 & $14^{\mathrm{a}}$ & $23^{\mathrm{a}}$ & $29^{\mathrm{a}}$ & $32^{\mathrm{a}}$ \\
\hline \multirow{3}{*}{ A. deflexus } & Control & 0 & $7^{\mathrm{b}}$ & $17^{\mathrm{b}}$ & $28^{\mathrm{a}}$ & $30^{\mathrm{a}}$ & $31^{\mathrm{a}}$ \\
\hline & PM & 0 & $5^{b}$ & $18^{\mathrm{ab}}$ & $25^{\mathrm{a}}$ & $28^{\mathrm{a}}$ & $30^{\mathrm{a}}$ \\
\hline & NPK & 0 & $10^{\mathrm{a}}$ & $20^{\mathrm{a}}$ & $28^{\mathrm{a}}$ & $34^{\mathrm{a}}$ & $38^{\mathrm{a}}$ \\
\hline
\end{tabular}

${ }^{*}$ Comparison is treatment-wise. Means with the same letter(s) within each species are not significant at $P<0.05$.

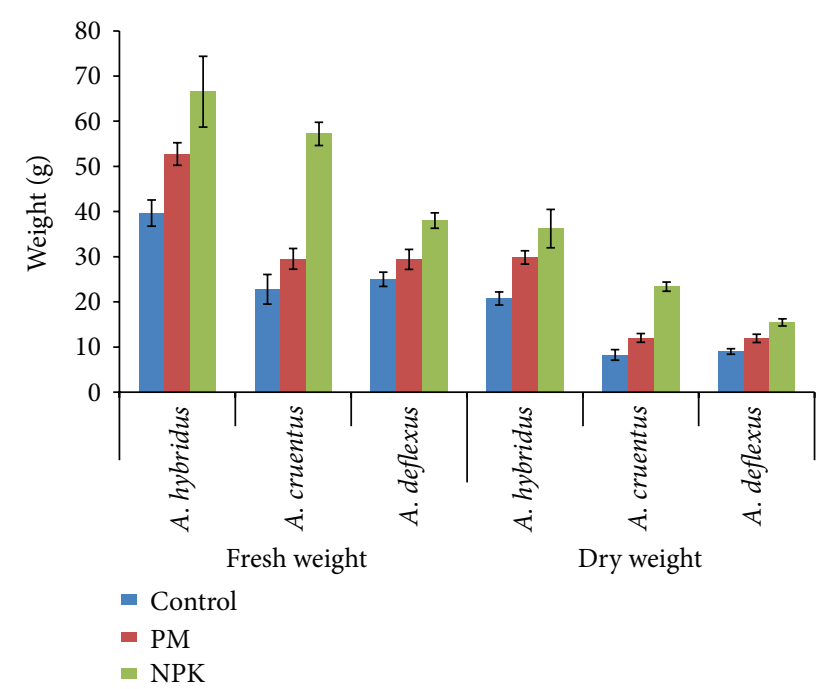

FIGURE 1: Fresh and dry weights of three amaranths grown in fertilized and unfertilized soil.

measured. Except for A. hybridus, protein content in the species grown in NPK-treated soil was significantly higher than that of other treatments, while plants in PM-treated soils had the highest ash content. Crude fibre in A. cruentus grown with PM was significantly higher than NPK and the control, contrary to that in A. hybridus and A. deflexus with the NPK treatment having the highest crude fibre. A. hybridus and A. cruentus grown with NPK had the higher lipid content than PM and the control, but A. deflexus from PM-treated soil had the highest lipid content. Except for A. hybridus, the carbohydrate contents in the Amaranthus grown with NPK were significantly lower than the control and PM. The moisture contents in these plants were also significantly lower than the control (Table 7). Generally, the protein and fibre contents in $A$. hybridus were significantly higher than those in A. cruentus and $A$. deflexus. But ash, lipid, and carbohydrate contents in all three species as well as the moisture content in A. cruentus and A. deflexus were at par (Figure 2).

\section{Discussion}

The slower growth in plants in NPK- and PM-fertilized soil during the early weeks after transplanting could be due to initial physiological changes associated with transplanting. This initial drawback after transplanting have been reported for tomato [14], rice [15], maize [16], and sorghum [17]. This effect was outweighed during the later weeks after transplanting (4-6 WAT) as $\mathrm{N}, \mathrm{P}$, and $\mathrm{K}$ release after mineralization significantly enhanced the growth parameters (leaf number, length and breadth, plant height, branching, and stem girth) 
TABLE 7: Proximate composition of three species of Amaranthus grown in control and fertilized soils (PM and NPK).

\begin{tabular}{lccccccc}
\hline Species & Treatment & \% Protein & \% Ash & \% Crude fibre & \% Lipid & \% Carbohydrate & \% Moisture \\
\hline \multirow{4}{*}{ A. hybridus } & Control & $15.23 \pm 0.51^{\mathrm{b}}$ & $8.63 \pm 0.21^{\mathrm{b}}$ & $16.17 \pm 0.59^{\mathrm{b}}$ & $4.40 \pm 0.10^{\mathrm{b}}$ & $7.87 \pm 0.06^{\mathrm{b}}$ & $47.70 \pm 0.17^{\mathrm{a}}$ \\
& PM & $16.03 \pm 0.21^{\mathrm{a}}$ & $11.17 \pm 0.15^{\mathrm{a}}$ & $14.67 \pm 0.12^{\mathrm{c}}$ & $4.30 \pm 0.26^{\mathrm{b}}$ & $10.37 \pm 0.25^{\mathrm{a}}$ & $43.47 \pm 0.15^{\mathrm{c}}$ \\
& NPK & $16.47 \pm 0.25^{\mathrm{a}}$ & $6.93 \pm 0.15^{\mathrm{c}}$ & $17.10 \pm 0.20^{\mathrm{a}}$ & $5.77 \pm 0.15^{\mathrm{a}}$ & $8.20 \pm 0.17^{\mathrm{b}}$ & $45.53 \pm 0.06^{\mathrm{b}}$ \\
& Control & $8.07 \pm 0.15^{\mathrm{c}}$ & $7.23 \pm 0.15^{\mathrm{c}}$ & $6.40 \pm 0.10^{\mathrm{c}}$ & $4.73 \pm 0.21^{\mathrm{c}}$ & $9.77 \pm 0.06^{\mathrm{a}}$ & $63.80 \pm 0.10^{\mathrm{a}}$ \\
A. cruentus & PM & $8.47 \pm 0.31^{\mathrm{b}}$ & $10.97 \pm 0.12^{\mathrm{a}}$ & $7.17 \pm 0.06^{\mathrm{a}}$ & $5.07 \pm 0.15^{\mathrm{b}}$ & $9.00 \pm 0.36^{\mathrm{b}}$ & $59.33 \pm 0.15^{\mathrm{b}}$ \\
& NPK & $9.37 \pm 0.06^{\mathrm{a}}$ & $9.80 \pm 0.10^{\mathrm{b}}$ & $6.77 \pm 0.06^{\mathrm{b}}$ & $6.43 \pm 0.06^{\mathrm{a}}$ & $8.47 \pm 0.15^{\mathrm{c}}$ & $59.17 \pm 0.15^{\mathrm{b}}$ \\
& Control & $8.37 \pm 0.15^{\mathrm{c}}$ & $6.97 \pm 0.21^{\mathrm{c}}$ & $5.47 \pm 0.15^{\mathrm{c}}$ & $4.80 \pm 0.10^{\mathrm{c}}$ & $10.47 \pm 0.21^{\mathrm{a}}$ & $63.93 \pm 0.15^{\mathrm{a}}$ \\
A. deflexus & PM & $8.67 \pm 0.15^{\mathrm{b}}$ & $8.30 \pm 0.10^{\mathrm{a}}$ & $6.47 \pm 0.15^{\mathrm{b}}$ & $6.97 \pm 0.15^{\mathrm{a}}$ & $10.20 \pm 0.10^{\mathrm{a}}$ & $59.40 \pm 0.10^{\mathrm{b}}$ \\
& NPK & $9.33 \pm 0.12^{\mathrm{a}}$ & $7.30 \pm 0.10^{\mathrm{b}}$ & $8.07 \pm 0.15^{\mathrm{a}}$ & $6.46 \pm 0.15^{\mathrm{b}}$ & $9.50 \pm 0.10^{\mathrm{b}}$ & $59.33 \pm 0.25^{\mathrm{b}}$ \\
\hline
\end{tabular}

* Comparison is treatment-wise. Means with the same letter(s) within each species are not significant at $P<0.05$.

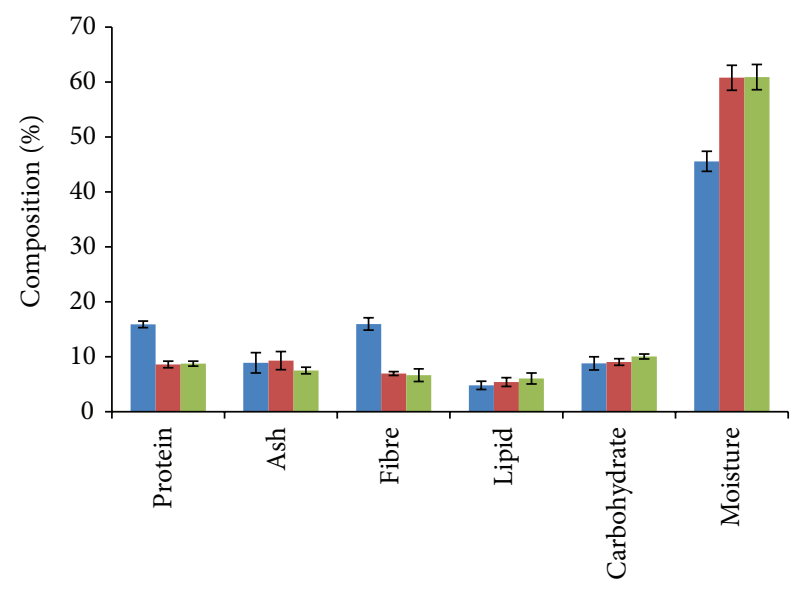

Proximate composition

$$
\begin{aligned}
& \text { - A. hybridus } \\
& \text { - A. cruentus } \\
& \text { - A. deflexus }
\end{aligned}
$$

Figure 2: Proximate composition of A. hybridus, A. cruentus, and A. deflexus.

in the three Amaranthus species. The higher performance of crops in NPK over PM is indicative of the ease of dissolution of nutrients in the inorganic fertilizer being in a more soluble form. Poultry manure also contains useful soil nutrients that are needed for the growth of plants [18], but their composition is in the crude form that is released slowly to the soil [19]. This possibly accounted for slower growth of plants in PMtreated soil to those of NPK and its higher performance than the control. This influence on growth by NPK and PM possibly resulted in higher yield than in the control. This result corroborates those of $[4,20,21]$ on growth of Amaranthus and that of [22] on yield of Amaranths.

The higher protein in the Amaranthus species grown with NPK and PM is consistent with the result of [22]. The increased nitrogen to the soil by the fertilizers increased the uptake by the Amaranthus resulting in increased protein. The ash content in PM plants was significantly higher possibly because of the balanced nutrient in the manure, unlike NPK with proportionate contents of $\mathrm{N}, \mathrm{P}$, and $\mathrm{K}$ and the control with lower concentration of nutrients. The significantly higher carbohydrate in the control plants of $A$. cruentus and $A$. deflexus also corroborates with those of [22]. Except for moisture content, the protein, fibre, fat, and carbohydrate composition in the three species were higher than those reported by [23]. The nutritional content of $A$. cruentus except for lipid was lower than that reported by [24]. Of the three species, only $A$. hybridus is considered a good source of protein as it accounts for more than $12 \%$ of its nutritional value [25]. This is contrary to the report by [1] in which $A$. cruentus was implicated as a rich source of protein accounting for $11.4 \%-14.1 \%$ of the proximate composition.

\section{Conclusion}

Except for the length, breadth, and number of leaves, growth parameters and yield were in the order NPK > PM > control. Amaranthus species grown with NPK significantly had higher protein, while those grown with PM had higher ash content. A. hybridus had the highest protein composition and could be considered a good source of vegetable protein when consumed. Both inorganic fertilizer (NPK) and organic (PM) increase soil fertility, but plants grown with inorganic fertilizer performed better. Since the Amaranthus grown with NPK and PM had better growth but differs in nutritional quality, the choice of the nutrient may influence determining the choice of manure to encourage.

\section{Conflict of Interests}

The authors declare that there is no conflict of interests regarding the publication of this paper.

\section{References}

[1] C. T. Onwordi, A. M. Ogungbade, and A. D. Wusu, "The proximate and mineral composition of three leafy vegetables commonly consumed in Lagos, Nigeria," African Journal of Pure and Applied Chemistry, vol. 3, no. 6, pp. 102-107, 2009.

[2] K. E. Law-Ogbomo, S. U. Remison, and E. O. Jombo, "Effect of organic and inorganic fertilizer on the productivity of Amaranthus cruentus," Nigerian Journal of Agriculture, Food and Environment, vol. 8, no. 2, pp. 35-40, 2012. 
[3] S. O. Ojeniyi, O. Owolabi, O. M. Akinola, and S. A. Odedina, "Field study of effect of organomineral fertilizer on maize growth yield soil and plant nutrient composition in Ilesa, southwest Nigeria," Nigeria Journal of Soil Science, vol. 19, pp. 11-16, 2009.

[4] J. O. Shiyam and W. B. Binang, "Effect of poultry manure and urea-n on flowering occurrence and leaf productivity of Amaranthus cruentus," Journal of Applied Sciences and Environmental Management, vol. 15, no. 1, pp. 13-15, 2011.

[5] J. B. J. van Ryssen, S. van Malsen, and A. A. Verbeek, "Mineral composition of poultry manure in South Africa with reference to the Farm Feed Act," South African Journal of Animal Science, vol. 23, no. 2, pp. 54-57, 1993.

[6] A. Mariakulandai and T. S. Manickam, "Phosphorus and phosphatic fertilizers," in Chemistry of Fertilizers and Manures, pp. 114-162, Asia Publishing House, New York, NY, USA, 1975.

[7] G. A. Ali, "Uses of manure and fertilizer as soil management Technique for sustainable crop production," Paper presented at workshop organized by Taraba State Local Government Service Commission on 8 and 9, December 2005.

[8] A. O. Ogungbile and J. Olukosi, "An overview of the problems of the resource-poor farmers in Nigeria," in Proceedings of the Nigerian National Farming Systems Research Network, Calabar, Nigeria, August 1990.

[9] S. Tsuyuzaki, "Rapid seed extraction from soil by floatation method," Seed Science and Technology, vol. 21, pp. 479-481, 1994.

[10] R. Osborne and P. Voogt, The Analysis of Nutrients in Foods, Academic Press, New York, NY, USA, 1978.

[11] AOAC (Association of Official Analytical Chemists), Official Methods of Analysis, Washington, DC, USA, 1990.

[12] E. Asibey and F. A. K. Taiye, "Proximate analysis of some underutilized Ghanian vegetables," Ghana Journal of Science, vol. 39, pp. 91-96, 1999.

[13] K. K. Eyeson and E. K. Ankrah, "Composition of foods commonly used in Ghana," UNDP/FAO Publication, Food Research Institute, Accra, Ghana, 1975.

[14] J. N. T. Mckee, "Physiological aspects of transplanting vegetable and other crops. I: factors which influence re-establishment," Horticultural Abstract, vol. 51, no. 5, pp. 262-268, 1981.

[15] K. S. Murthy and G. Sahu, "Effect of age of seedling at normal transplanting on growth and yield of rice varieties," Indian Journal of Agricultural Sciences, vol. 49, no. 10, pp. 797-801, 1979.

[16] A. S. Khahra, H. S. Brar, R. K. Sharma, B. S. Dhillon, and V. V. Malhotra, "Transplanting of maize during the winter in India," Agronomy Journal, vol. 82, pp. 41-47, 1990.

[17] G. O. Agbaje and J. A. Olofintoye, "Effect of transplanting on yield and growth of grain sorghum (Sorghum bicolor (L.) Moench)," Tropicultura, vol. 20, no. 4, pp. 217-220, 2002.

[18] L. S. Ayeni, E. O. Adeleye, and J. O. Adejumo, "Comparative effect of organic, organomineral and mineral fertilizers on soil properties, nutrient uptake, growth and yield of maize (Zea mays)," International Research Journal of Agricultural Science and Soil Science, vol. 2, no. 11, pp. 493-497, 2012.

[19] R. O. Nyankanga, R. N. Onwonga, F. S. Wekesa, D. Nakimbugwe, D. Masinde, and J. Mugisha, "Effect of inorganic and organic fertilizers on the performance and profitability of grain amaranth (Amaranthus caudatus L.) in Western Kenya," Journal of Agricultural Science, vol. 4, no. 1, pp. 223-232, 2012.

[20] E. A. Makinde, O. K. Oluwa, A. O. Oke, and P. O. Duyile, "Effects of organic, organomineral and NPK fertilizer treatments on fresh and dry matter yield of Amaranthus cruentus L. on soil types in Lagos, Nigeria," New York Science Journal, vol. 3, no. 4, pp. 12-17, 2010.

[21] J. N. Ainika and E. B. Amans, "Growth and yield response of vegetable Amaranth to NPK fertilizer and farmyard manure at Samaru, Nigeria," in Proceedings of 29th Annual National Conference of Horticultural Society of Nigeria (HORTSON '11), July 2011.

[22] F. O. Adekayode, "The use of manure to increase the yield and quality of Amaranthus to feed rabbit in a humid tropical region," Journal of Animal and Veterinary Advances, vol. 3, no. 11, pp. 758-762, 2004.

[23] K. Sheela, K. G. Nath, D. Vijayalakshmi, G. M. Yankanchi, and R. B. Patil, "Proximate composition of underutilized green leafy vegetables of southern Karnataka," Journal of Human Ecology, vol. 15, no. 3, pp. 227-229, 2004.

[24] A. O. Fasuyi, F. A. S. Dairo, and A. O. Adeniji, "Tropical vegetable (Amaranthus cruentus) leaf meal as alternative protein supplement in broiler starter diets: Bionutritional evaluation," Journal of Central European Agriculture, vol. 9, no. 1, pp. 23-33, 2008.

[25] D. Pearson, Chemical Analysis of Foods, Churchill Livingstone, London, UK, 7th edition, 1976. 

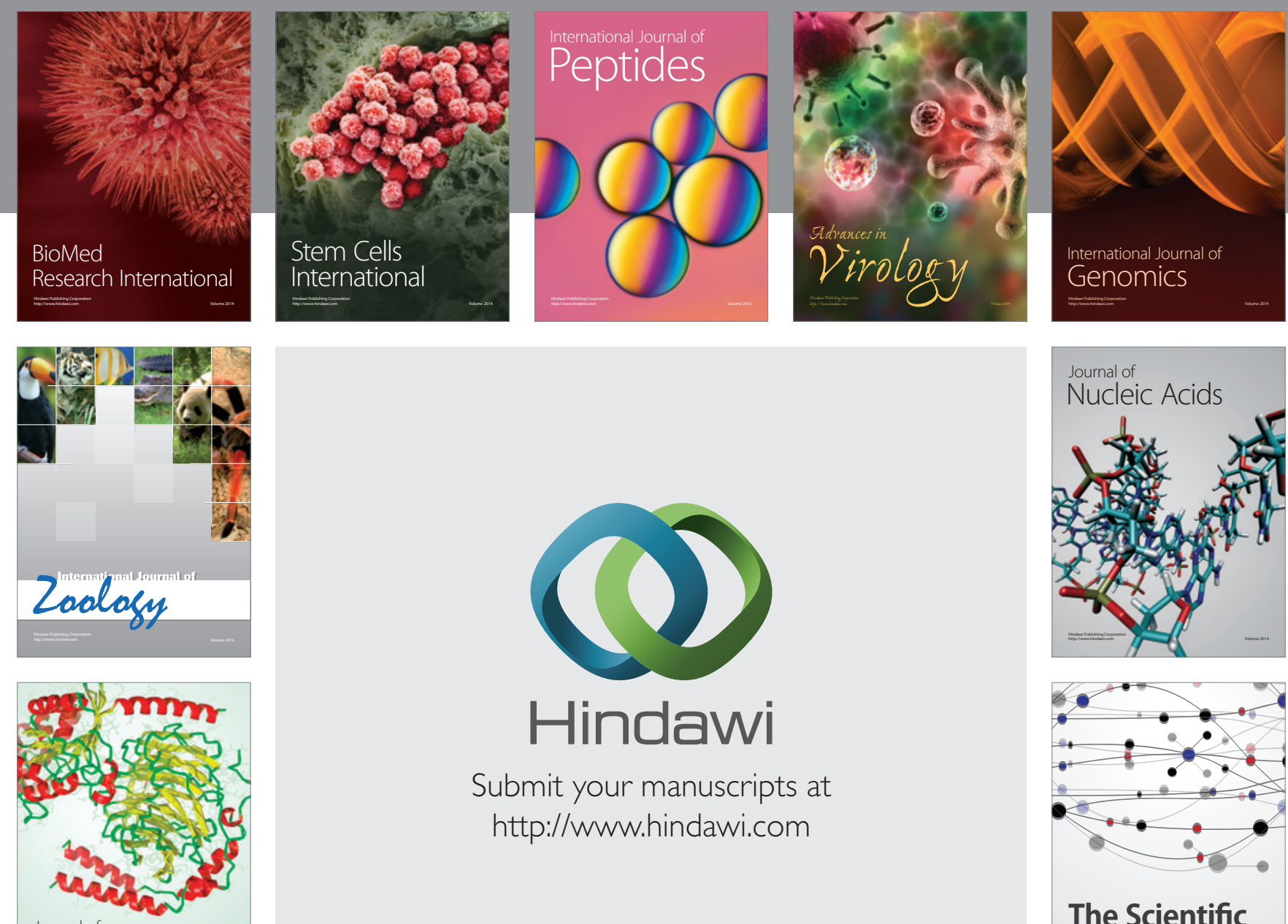

Submit your manuscripts at

http://www.hindawi.com

Journal of
Signal Transduction
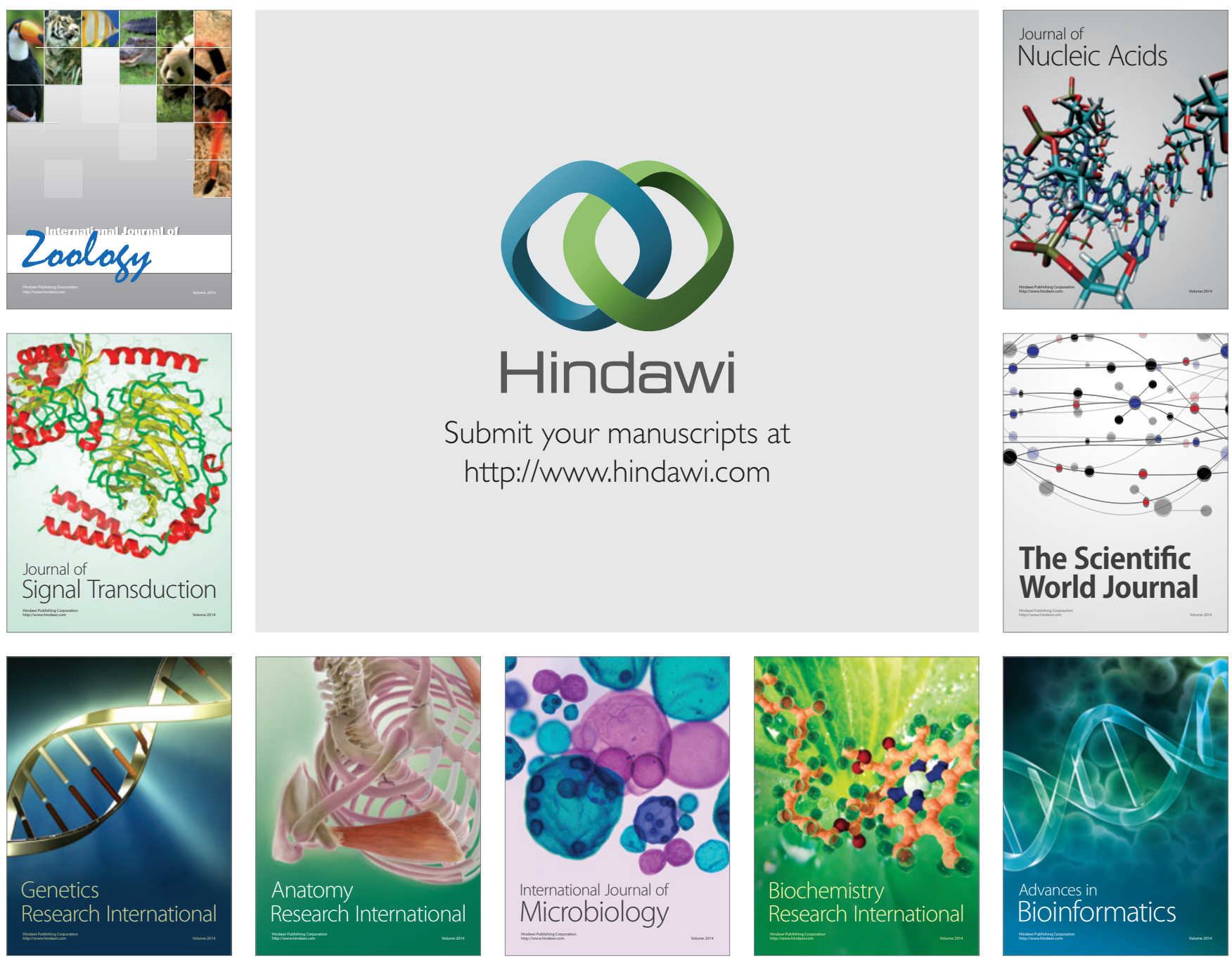

The Scientific World Journal
